\section{PEMBUKUAN KEUANGAN BAGI UMKM BINAAN POSDAYA CEMPAKA}

Ameilia Damayanti ${ }^{1}$, Nelyumna ${ }^{2}$, Widyaningsih Azizah ${ }^{3}$, Bella Rusania Tisan $\mathrm{Lie}^{4}$

${ }^{1,2,3,4}$ Fakultas Ekonomi dan Bisnis Universitas Pancasila, Jakarta

Diterima : 03 Juli 2021

Disetujui : 21 Juli 2021

Email :

amel.damay@univpancasila.ac.id

\begin{abstract}
Abstrak
Merujuk pada usaha ekonomi produktif, perkembangan jumlah UMKM dari tahun ke tahun semakin bertambah, namun perkembangan UMKM baru terlihat dari sisi jumlahnya saja. Secara aspek finansial belum banyak UMKM yang mengalami perkembangan dalam hal kinerja keuangannya. Hal ini karena kurangnya kesadaran pelaku UMKM terhadap pentingnya pengelolaan keuangan dari usaha yang sedang dijalani. Ada berbagai macam permasalahan yang umumnya dihadapi dalam meningkatkan keberhasilan dari UMKM, salah satunya yaitu lemahnya aspek pencatatan laporan keuangan. UMKM diharapkan bisa membuat laporan keuangan yang baik sesuai dengan Standar Akuntansi Keuangan (SAK) di Indonesia. Saat ini UMKM di Posdaya Cempaka masih dilakukan secara sederhana, pencatatan dilakukan hanya sebatas arus kas masuk dan kas keluar. Selain itu uang yang diperoleh dari usaha digabung dengan uang rumah tangga dan pengeluaran untuk kebutuhan rumah tangga juga menggunakan hasil dari usaha sehingga ada pelaku UMKM tidak melakukan pencatatan. Para peserta UMKM diberikan wawasan terkait pentingnya pencatatan bagi UMKM untuk menghasilkan laporan keuangan yang bisa digunakan sebagai pengambilan keputusan.
\end{abstract}

Kata Kunci: Pembukuan keuangan, UMKM, laporan keuangan

\begin{abstract}
Referring to productive economic business, the development of the number of MSMEs is increasing from year to year, however the development of MSMEs is only seen in terms of numbers, however the development of MSMEs can only be seen from its quantity. Yet, in financial performance, only few MSMEs has developed. This is due to the lack of awareness of MSME actors on the importance of financial management the business being undertaken. There are various kinds of problems that are generally faced in increasing the success of MSMEs, one of which is the weak aspect of recording financial statements. MSMEs are expected to be able to make good financial reports in accordance with Financial Accounting Standards (SAK) in Indonesia. FEB Univ Pancasila in collaboration with UMKM Posdaya Cempaka Jagakarsa in the context of currently UMKM in Posdaya Cempaka is still carried out in a simple manner, recording is only limited to cash inflows and cash outflows. In addition, the money obtained from the business is combined with household money and then expenditures for household needs also use the results from the business so that there are MSME actors who do not record. MSME participants were given insight regarding the importance of recording for MSMEs to produce financial reports that can be uses as decision making.
\end{abstract}

Keywords: Financial bookkeeping, MSMEs, Financial Reports 


\section{PENDAHULUAN}

Laporan keuangan merupakan alat untuk menganalisis kinerja keuangan yang bisa memberikan informasi tentang posisi keuangan, arus kas dan kinerja dari suatu usaha yang bisa digunakan untuk pengambilan keputusan bagi para penggunanya dan juga sebagai bentuk pertanggungjawaban manajemen atas penggunaan dari sumber daya yang dimiliki. Jadi setiap usaha besar, menengah ataupun kecil diharapkan mempunyai laporan keuangan tersebut sebagai bahan pertimbangan dan pengambilan keputusan untuk usahanya. Hal ini juga berlaku untuk Usaha Mikro, Kecil dan Menengah (UMKM) sebagai badan usaha atau perorangan yang merujuk pada usaha ekonomi produktif. Perkembangan jumlah UMKM dari tahun ke tahun juga semakin bertambah, namun perkembangan UMKM baru terlihat dari sisi jumlahnya saja, secara aspek finansial belum banyak UMKM yang mengalami perkembangan dalam hal kinerja keuangannya. Hal ini karena kurangnya kesadaran pelaku UMKM terhadap pentingnya pengelolaan keuangan dari usaha yang sedang dijalani.

\section{Analisis Situasi}

Menurut Ria (2018) Ada berbagai macam permasalahan yang umumnya dihadapi dalam meningkatkan keberhasilan dari UMKM, antara lain aspek permodalan, bahan baku, dan lemahnya pengetahuan di berbagai aspek manajemen dan sumber daya manusia, serta lemahnya aspek pencatatan laporan keuangan. Kelemahan pencatatan laporan keuangan diperparah dengan banyak UMKM beranggapan tidak perlu menyusun laporan keuangan, yang terpenting bagi mereka usahanya menguntungkan (Fujianti et al. 2020). Di samping itu UMKM belum dapat atau enggan untuk memisahkan antara harta pribadi dan harta usaha. UMKM pada umumnya juga tidak dapat menghitung biaya produksi secara akurat (Fujianti et al. 2021) karena seringkali yang dihitung hanyalah bahan baku sedangkan tenaga dan biaya overhead seringkali diabaikan.

Ada juga beberapa UMKM melakukan penyusunan laporan keuangan akan tetapi masih bersifat manual dan hanya mencatat arus kas masuk dan keluarnya saja sehingga pencatatannya menjadi kurang akurat dan mengakibatkan UMKM mengalami kesulitan untuk mengakses pinjaman melalui perbankan. Kelemahan pencatatan secara manual dapat diatasi dengan aplikasi khusus pencatatan berbasis handphone (Fujianti et al. 2019) karena hampir semua pelaku UMKM sudah terbiasa dengan penggunaan handphone.

UMKM sebaiknya dapat menyusun laporan keuangan, sehingga mereka dapat mengetahui kondisi usahanya dalam posisi menguntungkan atau sebaliknya tidak menguntungkan. Laporan ini berguna sebagai sebagai bahan evaluasi usahanya serta sebagai input tindakan atau rencana apa yang akan dilaksanakan guna memajukan usaha yang dijalankan. Penyusunan laporan yang baik sebenarnya harus sesuai dengan Standar Akuntansi Keuangan (SAK) di Indonesia. Melihat kondisi UMKM yang belum mampu mengikuti SAK yang berlaku maka dibentuk Standak Akuntansi untuk Entitas Tanpa Akuntabilitas Publik (SAK ETAP) dan sejak tanggal 1 Januari 2018 standar ini dinyatakan berlaku efektif. SAK-EMKM (Standar Akuntansi Keuangan Entitas Mikro Kecil 
Menengah) adalah standar akuntansi untuk entitas yang tidak memiliki akuntabilitas kepada publik untuk mempermudah pelaporan keuangan UMKM.

\section{Tujuan Kegiatan}

Kegiatan Pelatihan ini bertujuan untuk meningkatkan pemahaman dan kesadaran pelaku UMKM binaan Posdaya Cempaka di Jagakarsa Selatan untuk menghitung, melakukan pembukuan dan pencatatan akuntansi UMKM. Pelatihan ini adalah sebagai wujud nyata peran Fakultas Ekonomi dan Bisnis (FEB) Universitas Pancasila dan LPPM dalam peningkatan kesadaran khususnya pada pelaku UMKM.

\section{Target Luaran}

Adapun target dan luaran dari kegiatan pengabdian masyarakat ini adalah sebagai berikut:

1. Sasaran kepesertaan dari kegiatan ini adalah pelaku UMKM yang aktif di UMKM binaan Posdaya Cempaka di Jagakarsa Selatan.

2. Kegiatan ini diharapkan dapat meningkatkan kemampuan para pelaku UMKM binaan Posdaya Cempaka di Jagakarsa Selatan dalam membuat pembukuan akuntansi dan melaporkan kinerja usahanya dalam bentuk laporan keuangan yang sesuai dengan standar akuntansi yang berlaku.

Produk pengabdian ini berupa dokumen yang berisi modul pembukuan yang bisa dimanfaatkan oleh pelaku UMKM dan dinas terkait untuk jangka panjang, serta rekaman video tutorial penggunaan aplikasi digital untuk penyusunan laporan keuangan

\section{METODE}

Pengabdian kepada masyarakat berupa pelatihan pembukuan keuangan ini diperuntukkan kepada UMKM yang aktif dan beroperasi di binaan Posdaya Cempaka di Jagakarsa Selatan. Waktu pengabdian dilakukan pada tanggal 07 Juni 2021. Sebelum kegiatan pengabdian dilaksanakan, Unit Penelitian dan Pengabdian (P2M) Fakultas Ekonomi dan Bisnis Universitas Pancasila (FEB-UP) melakukan komunikasi melalui telepon dengan ketua tim posdaya Cempaka di Jagakarsa. Dikarenakan kondisi di Indonesia yang sedang dilanda oleh pandemi virus Corona, maka seluruh aktivitas pengabdian dilakukan secara daring melalui media Zoom.

Selanjutnya, pihak Posdaya terkait memberikan informasi terkait dengan data peserta UMKM yang telah mendaftar dan bersedia mengikuti kegiatan pengabdian kepada masyarakat. Dari data yang diperoleh dari Posdaya Cempaka terkait terdapat 15 pelaku usaha dengan berbagai jenis usaha seperti warung sembako, tempat makan, dan lainnya. Supaya kegiatan pelatihan berjalan secara efektif dan efisien, setiap peserta diminta untuk menyatakan kesediaannya mengikuti seluruh sesi pelatihan dan pendampingan yang ditawarkan. Hal ini bertujuan sebagai antisipasi agar pelaku usaha tidak hanya hadir di awal sesi saja, tetapi hadir di seluruh sesi kegiatan sehingga menerima materi secara utuh, karena pelatihan dan pendampingan ini bersifat sistematis. Setelah seluruh persiapan dan kesepakatan 
dengan peserta UMKM, selanjutnya kegiatan pengabdian masyarakat dilaksanakan sesuai dengan waktu yang telah ditentukan sebelumnya.

\section{PEMBAHASAN}

\section{Proses Kegiatan}

Kegiatan pengabdian kepada masyarakat ini dilakukan dengan melakukan pelatihan pembukuan keuangan dengan pemberian materi arti penting pencatatan bagi UMKM. Kegiatan ini dilakukan secara daring melalui media ZOOM dan waktu pengabdian dilakukan pada tanggal 07 Juni 2021. Kegiatan dimulai dengan membuat grup pada aplikasi whatsapp dengan tujuan agar dapat memudahkan koordinasi dengan tim pengabdian dan peserta UMKM. Dikarenakan seluruh kegiatan dilakukan secara daring, maka pembagian tugas dan koordinasi kepada anggota tim dosen yang terlibat selama acara didiskusikan seluruhnya melalui grup whatsapp dan zoom. Selanjutnya anggota tim dosen lainnya bertugas dan berperan aktif dalam menjawab pertanyaan dan membantu peserta pelatihan melalui media chat yang tersedia di ZOOM selama acara dilaksanakan. Setelah semua persiapan telah dilakukan, selanjutnya kegiatan pengabdian masyarakat dilaksanakan.

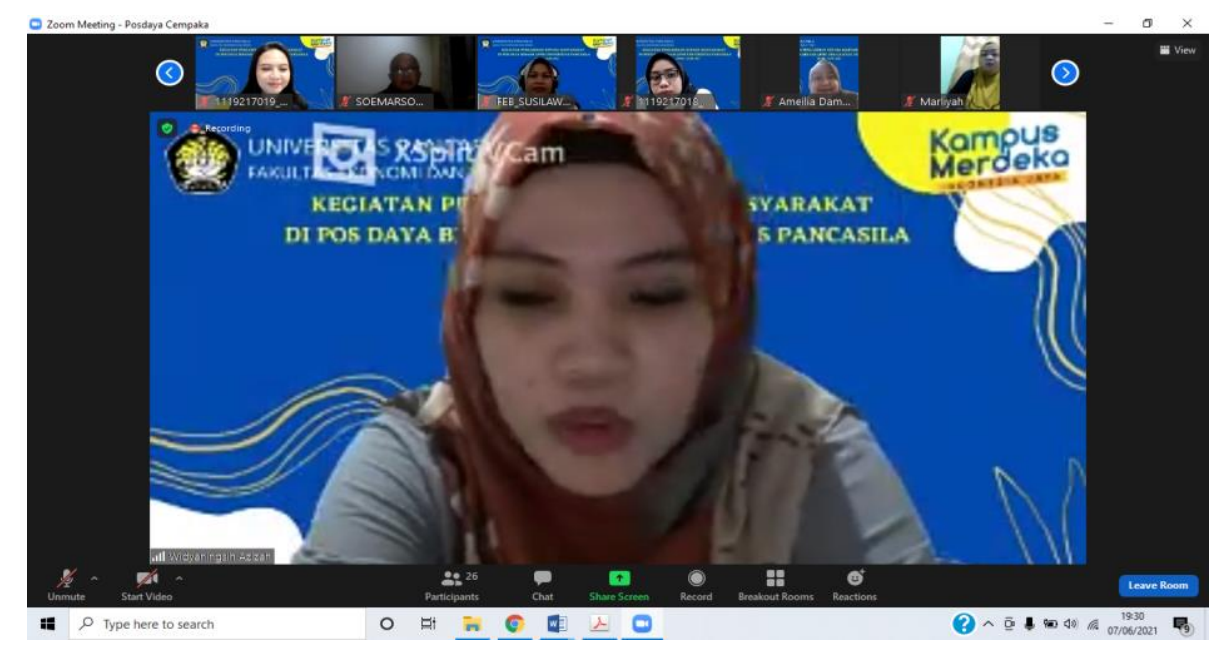

Gambar 1. Pemaparan Materi

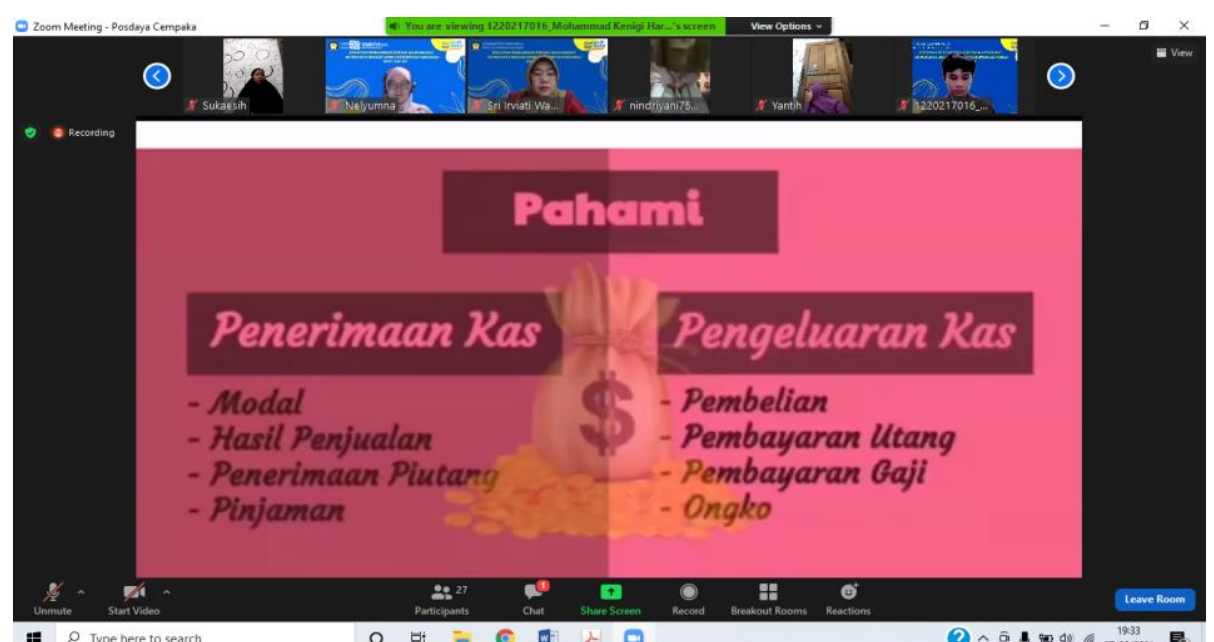

Gambar 2. Materi Pelatihan 


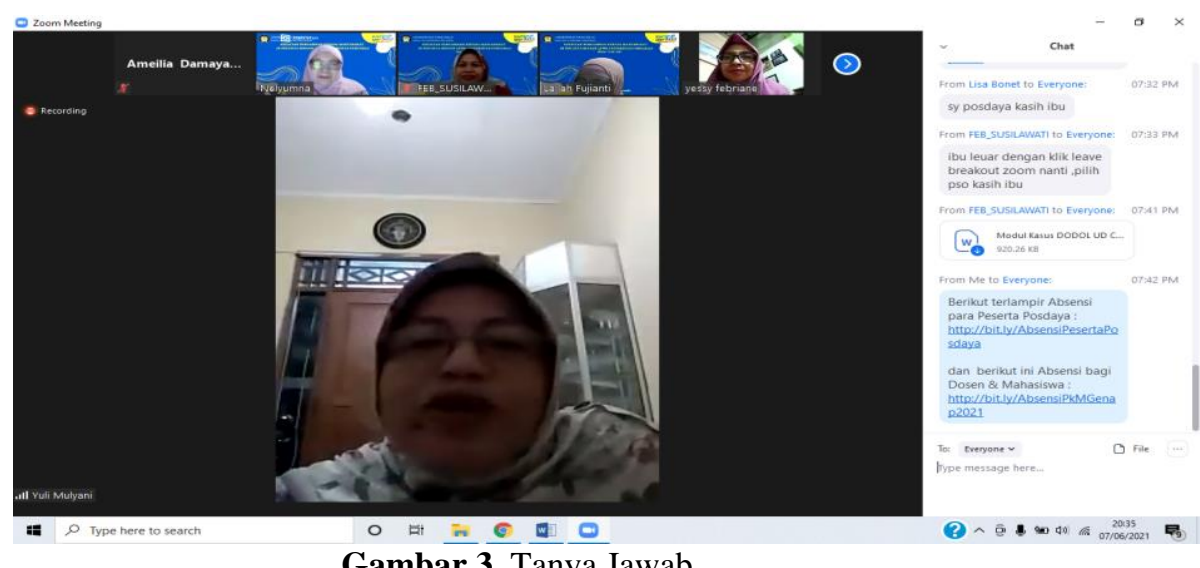

Gambar 3. Tanya Jawab

Kegiatan ini diawali dengan sambutan yang disampaikan oleh Ibu Dr. Lailah Fujianti, SE., M.Si., Ak, CA selaku Wakil Dekan I Fakultas Ekonomi dan Bisnis Universitas Pancasila. Setelah itu acara dilanjutkan dengan pemaparan materi pelatihan Arti Penting Pencatatan Bagi UMKM yang dipaparkan oleh narasumber yaitu Ibu Widyaningsih Azizah, SE., M.Si., Ak., CA. Diskusi dan tanya jawab mengenai berbagai kendala yang dihadapi UMKM dalam melakukan pembukuan keuangan.

\section{Hasil Pelaksanaan Kegiatan}

Perkembangan teknologi yang cepat menuntut para pelaku UMKM untuk tetap up to date dengan kemajuan. Saat ini UMKM di Posdaya Cempaka masih dilakukan secara sederhana, pencatatan dilakukan hanya sebatas arus kas masuk dan kas keluar. Selain itu uang yang diperoleh dari usaha digabung dengan uang rumah tangga lalu pengeluaran untuk kebutuhan rumah tangga juga menggunakan hasil dari usaha sehingga ada pelaku UMKM tidak melakukan pencatatan. Para peserta UMKM diberikan wawasan terkait pentingnya pencatatan bagi UMKM untuk menghasilkan laporan keuangan yang bisa digunakan sebagai pengambilan keputusan. selama pelaksanaan pelatihan direkam menggunakan fasilitas rekaman yang ada pada ZOOM. Selama pelatihan berlangsung, peserta bisa mengajukan pertanyaan secara langsung kepada narasumber maupun tim dosen melalui media chat pada ZOOM.

Pelatihan Pembukuan Keuangan untuk UMKM Binaan Posdaya Cempaka dimulai pukul 19.00 WIB diawali dengan pemaparan yang disampaikan oleh ibu Widyaningsih Azizah, SE., M.Si., Ak., CA yang menjelaskan tentang arti pentingnya pencatatan bagi UMKM. Materi pertama ini peserta diberikan pengetahuan tentang penjelasan pentingnya pencatatan dalam akuntansi dan manfaat dari pencacatan tersebut untuk kegiatan usaha. Hal ini dimaksudkan agar para pelaku UMKM memahami dan menyadari pentingnya dilakukan pencatatan pembukuan keuangan. Pelaksanaan pengabdian masyarakat ini berdampak positif terhadap pelaku UMKM. Pertama mengetahui jumlah keuntungan atau kerugian usaha yang dijalani secara tepat. 


\section{SIMPULAN}

\section{Kesimpulan}

Secara umum, sebagian besar peserta pelatihan di UMKM Binaan Posdaya Cempaka Jagakarsa dapat memahami dan mengerti arti penting dari pembuatan pembukuan keuangan yang diberikan dan mulai menyadari bahwa pembukuan keuangan sangat dibutuhkan agar bisa mengendalikan keuangan usahanya. Pada kegiatan pengabdian tersebut para pelaku UMKM memiliki minat dan keinginan yang kuat untuk mampu membuat pembukuan keuangan supaya bisa memisahkan antara uang yang dimiliki pribadi dengan hasil usahanya, hanya saja mereka terhambat pada kemampuan memahami akuntansi, perhitungan dan tata caranya menggunakannya.

\section{Saran}

Saran yang dapat diberikan sehubungan dengan kegiatan pengabdian masyarakat ini, adalah sebagai berikut:

1. Pelatihan ini bisa diaplikasikan pada ruang lingkup yang lebih luas sehingga edukasi terkait pembukuan keuangan untuk UMKM cakupannya lebih banyak.

2. Dengan adanya pelatihan ini, pelaku UMKM dapat memahami dan mengerti arti penting dari pembuatan pembukuan keuangan sampai dengan menyusunan Laporan Keuangan dengan baik agar dapat menghitung, dan membuat laporan keuangan sederhana, bukan hanya sekedar uang masuk dan uang keluar.

3. Model pelatihan seperti ini juga dapat dijadikan sebagai model pendampingan pelengkap bagi instansi pemerintahan yang rutin mengadakan pembinaan UMKM, dengan menambahkan aspek monitoring dan evaluasi secara berkala untuk mengukur efektivitas pelatihan dan pendampingan.

\section{DAFTAR PUSTAKA}

Damayanti, Ameilia., Susilawati., Ahmad Ali Akbar Aslamy. 2021. Pelatihan Penyusunan Pelaporan PPh Badan Bagi UMKM Kecamatan Sekayu Kabupaten Musi Banyuasin. Abdi Implementasi Pancasila : Jurnal Pengabdian Masyarakat. Vol. 1 (1) : 22-27

Fidela, Alifah., Pratama, Aprinaldi., Nursyamsiah, Tita. 2020. Pengembangan Usaha Mikro Kecil dan Menengah (UMKM) dengan Program Pemasaran Desa Jambu Raya di Desa Jambu, Kabupaten Sumedang. Jurnal Pusat Inovasi Masyarakat, Vol 2 (3) 2020: 493-498.

Fujianti, Lailah., Nelyumna., Rafrini Amyulianthy., Athania Mahardiyanti. 2020. Peningkatan Keahlian Pembukuan UMKM Kuliner Binaan PT Sinar Sosro Cempaka Putih Jakarta. SULUH Jurnal Abdimas. Vol 2 (1) : 78-88

Fujianti., Lailah., Harimurti Wulandjani., Susilawati. 2019. Peningkatan Keterampilan Akuntansi Berbasis Teknologi Informasi Bagi UMKM Batik Cirebon. SULUH Jurnal Abdimas. Vol 1 (1) : 21-27

Fujianti, Lailah., Shinta Budi Astuti., Rizki Ramadhan Putra Yasa . 2021. Perhitungan Harga Pokok Produksi (Cost) Hasil Produk Inovatif Umkm Desa Kemuning Ngargoyoso, Jawa Tengah. SULUH Jurnal Abdimas. Vol 2 (2) : 89-96

Purba, M. A. (2019). Analisis Penerapan Sak Emkm Pada Penyusunan Laporan Keuangan Umkm Di Kota Batam. Jurnal Akuntansi Barelang, 3(2), 55. https://doi.org/10.33884/jab.v3i2.1219 
Ria, Anita.2018. Analisis Penerapan Aplikasi Keuangan Berbasis Android Pada Laporan Keuangan UMKM Mekarsari, Depok. Sosio e-kons, Vol 10, No.3 Desember 2018, pp 207-219. http://dx.doi.org/10.30998/sosioekons.v10i3.2844

Sulistyowati, Yayuk. 2017. Listing Registration of SME Financial Reporting (A Case Studi in Malang). Jurnal Ilmu Manajemen dan Akuntansi Vo.5 No.2 Desember 2017.

Tarmizi, R., \& Bugawanti, N. L. S. 2013. Pengaruh Persepsi Pengusaha Kecil dan Menengah Terhadap Penggunaan SAK ETAP Di Kota Bandar Lampung. ISSN 2087 - 2054, 5(2)

Warsono, S. dan E. Murti. 2010. Akuntansi UMKM Ternyata Mudah Dipahami dan Dipraktikkan. Yogyakarta: Asgard Chapter Winarno. 